\title{
VIII. Note on Mynes Guerini, Wallace.
} By W. H. Miskin.

[Read 17th November, 1873.]

Is "Notes on Eastern Butterflies," contained in the Transactions of the Entomological Society of London for 1869, p. 77, Mr. Wallace, treating on the genus Mynes (Westwood), describes an insect in his collection (a female), from this colony, and, considering it distinct from $M$. Geoffroyi (Guérin), makes it a new species under the above name.

Having been so fortunate as to secure a tolerably perfect series of this very rare insect, I propose to offer a description of my specimens, comprising individuals of both sexes, and also a few remarks based upon my observations of these and examination of several specimens in some other collections.

The result of my investigations is to raise a doubt in my mind as to the correctness of Mr. Wallace's conclusion, that our species is distinet from $M$. Geoffroyi.

It will be observed that very considerable variation exists in the individuals I describe, both in dimensions and markings, and I have noticed the same inconstancy prevailing in other specimens that $I$ have examined beside my own. This is more particularly noticeable in the female, the males as a rule being tolerably consistent in their appearance, except in the case of the decided variety I have described, and which, singularly enough, appears to be almost identical with the specimen from Dorey described by Mr. Wallace; this fact of itself should, I imagine, be alone sufficient to establish the identity of our species with M. Geoffroyi. Other points of difference upon which Mr. Wallace distinguishes his species are not sufficiently important, I respectfully suggest, to justify the separation of these insects into distinct species, especially taking into consideration the peculiarly variable disposition I have shown to exist in the species.

TRANS. ENT. SOC. 1874.-PART II. (APR.) 
A. Male.-Anterior wings with broad margin of deep black on outer side, widest at top, where it extends about one-third along the costa, but decreasing in width towards the hinder margin, where it is less than one-fourth the width of the wing; the whole of the rest of the wing is one uniform shade of greenish-white; the inner edge of the black margin is sharply and clearly defined; at the apical angle and within the black margin are a series of three irregularlyshaped and different-sized white spots describing an arc.

Posterior wings.-Ground colour same as front wings, with a tolerably wide outer margin extending to the anal angle; this margin for about one-third of the way down is deep black, the remainder of a slaty-green colour.

Under side.-Both wings dark brown, nearly black, the front wings alone have a wide inner margin of white; the apical spots of the upper side are here replaced by a curved band of deep yellow, there is also a small patch of white about half-way along the costa; midway along the outer margin, but not quite touching the edge, is a spot of ochreous-red.

At the base of the posterior wing, and extending about one-third of the way along the front border, is a band of ochreous-red; while also, starting from the base, but bordering the anal margin, and turning a little way into the wing (where it is gradually lost) before reaching the anal angle, is a band of bright yellow; the outer border is marked by a line of white continuing round to the anal angle; within this is a marginal band of black, and between the two is another narrow whitish band; this latter is interrupted in the tailed portion of the wing by a band of dusky yellow; the tail is bordered by a row of lunule-shaped black patches; breast bright yellow.

Expanse of wings $2 \frac{5}{16}$ inches.

Hab.-Rockhampton.

B. Female.-Anterior wings with nearly two-thirds of the outer portion black, rest of wing cloudy white; inner edge of black is not sharply defined as in the $\delta$.

Posterior wings. - The outer black margin extending a considerable distance along the front border, and nearly round to the anal angle; this margin, for some distance from its termination, does not touch the edge of the wing, but is bordered on each side by dusky slaty green, amongst which it loses itself before reaching the anal angle; the 
latter colour gets gradually lighter in the dise of the wing, until, reaching the base, it is nearly white.

Under side.-Same as in the ox, excepting that the posterior wing has a narrow band of dusky yellow running parallel with but at some distance from the outer margin; this band is more or less defined, but is most distinct at its commencement from the front margin, it continues round until it meets the bright yellow band starting from the base.

Expanse of wings $2 \frac{9}{16}$ inches.

Hab.-Nerang Creek.

C. Female--Upper side almost same as preceding, not quite so much black on front wing; the hind wing with hardly any black margin, the dark green continuing from the outer border some distance in, and then gradually getting lighter towards the base. Under side same as preceding.

Expanse of wings $2 \frac{1}{16}$ inches.

Hab.-Brisbane (bred).

D. Male.-Variety.-Upper side presents the usual appearance in this sex as described in first specimen, having the deep black, sharply-defined, and narrow marginal band.

Under side.-The posterior wings present exactly the appearance described by $\mathrm{Mr}$. Wallace in his variety of $\boldsymbol{M}$. Geoffroyi from Dorey; in addition the front wings are also nearly wholly white, the only black part being the costal margin and the apical portion containing the white, yellow, and red spots; nor is there much of the dark colour left in the hind wings, excepting a band along the front margin, the posterior portion beneath the white spot (which nearly traverses the wing) being succeeded by bands of ashy-yellow interlined with white; the base of the wing is broadly suffused with rich yellow.

Expanse of wings $2 \frac{1}{4}$ inches.

Hab.-Rockhampton.

This last specimen was taken in company with others presenting the ordinary form, and is exactly similar to another specimen I have seen from Mackay.

A very singular feature (one that $I$ do not remember ever having heard of as prevailing amongst any of the Rhopolocera) exists in the economy of this insect, viz., the fact of the larvæ (which are gregarious in their habits) 
pursuing their social instincts, even to their assuming the pupa state, the chrysalides being found suspended together in a little group of three or four individuals united at the tails. I have never been so fortunate as to trace this insect through its various stages myself, but a lamented friend upon one occasion, some years ago, reared a brood from the larvæ; and a group of the pupa skins so united still remain in a drawer of his cabinet, which has now, however, passed into other hands. 


\section{$2 \mathrm{BHL}$ Biodiversity Heritage Library}

Miskin, William Henry. 1874. "VIII. Note on Mynes Guerini, Wallace." Transactions of the Entomological Society of London 22, 237-240. https://doi.org/10.1111/j.1365-2311.1874.tb00166.x.

View This Item Online: https://www.biodiversitylibrary.org/item/51650

DOI: https://doi.org/10.1111/j.1365-2311.1874.tb00166.x

Permalink: https://www.biodiversitylibrary.org/partpdf/27161

\section{Holding Institution}

Smithsonian Libraries

\section{Sponsored by}

Smithsonian

\section{Copyright \& Reuse}

Copyright Status: NOT_IN_COPYRIGHT

This document was created from content at the Biodiversity Heritage Library, the world's largest open access digital library for biodiversity literature and archives. Visit BHL at https://www.biodiversitylibrary.org. 